Hal $21-28$

\title{
IMPLEMENTASI METODE EKSPERIMEN DALAM PEMBELAJARAN MATERI GELOMBANG MEKANIK UNTUK MENINGKATKAN HASIL BELAJAR FISIKA SISWA KELAS XI MIPA SMA
}

\author{
TOTO PRIYONO BANI
}

SMA Muhammadiyah 3 Yogyakarta

toto.pb.007@gmail.com

\begin{abstract}
Abstrak
Penelitian ini bertujuan untuk mengetahui implementasi metode eksperimen dalam meningkatkan ketrampilan bereksperimen dan mengetahui peningkatan hasil belajar siswa kelas XI MIPA SMA. Peneliti berperan sebagai pengajar langsung di Kelas XI MIPA SMA. Penelitian ini dilakukan dalam siklus-siklus, tiap siklusnya terdiri dari satu kali praktikum. Model penelitian tindakan kelas yang dipakai adalah model Spiral dan Taggart. Materi yang diajarkan melalui metode eksperimen pada penelitian tindakan kelas ini adalah gelombang mekanik. Berdasarkan Penelitian Tindakan Kelas melalui dua siklus yang telah dilakukan pada siswa kelas XI MIPA SMA mata pelajaran fisika materi gelombang mekanik, dapat disimpulkan bahwa: Penggunaan metode eksperimen dalam pembelajaran fisika dapat meningkatkan nilai rata-rata keterampilan eksperimen siswa dari 62,1 menjadi 66,2. Pembelajaran fisika dengan metode eksperimen dapat meningkatkan hasil belajar siswa yang ditandai dengan peningkatan nilai rata-rata hasil pretest sebesar 47,3 postest siklus I sebesar 55,2 meningkat menjadi 60,5 pada siklus II.
\end{abstract}

Kata kunci: metode eksperimen, gelombang mekanik, hasil belajar fisika

\begin{abstract}
This study aims to determine the implementation of the experimental method in learning outcomes in grade XI MIPA High School. Researcher acts as a direct instructor in grade XI MIPA High School. This research was conducted in cycles, each cycle consisted of one practicum. The class action research model used is the Spiral and Taggart model. The material taught through the experimental method in Class Action Research is mechanical waves. Based on Classroom Action Research through two cycles that had been carried out on students of class XI MIPA High School Physics class under the subject of mechanical wave, it can be concluded that: The use of experimental methods in physics learning can increase the average value of students' experimental skills from 62.1 to 66.2 . Physics learning with experimental methods can improve student learning outcomes which are characterized by an increase in the average value of pretest results by 47.3 while posttest Cycle I which was 55.2 increased to 60.5 in Cycle II.

Keywords: experimental methods, mechanical waves, physics learning outcomes
\end{abstract}

\section{PENDAHULUAN}

Materi gelombang mekanik merupakan salah satu materi dalam pelajaran Fisika SMA yang mengandung konsep abstrak, konsep terdefinisi, dan hukum sehingga siswa kesulitan dalam memahami dan mempelajari materi yang disampaikan guru. Dalam menyajikan pembelajaran di kelas guru jarang menggunakan metode yang bervariasi sehingga siswa merasa jenuh atau bosan dan kurang berminat dalam mengikuti pembelajaran. Hal tersebut berdampak pada keaktifan siswa dan nilai siswa yang kurang maksimal. Permasalahan 
tersebut dapat di atasi, salah satunya dengan menggunakan metode eksperimen dalam proses pembelajaran.

Menurut Roestiyah (2012), metode eksperimen adalah salah satu cara mengajar yang memfasilitasi siswa melakukan percobaan tentang sesuatu hal, mengamati prosesnya, serta menuliskan hasil percobaannya.

Metode eksperimen memudahkan siswa untuk berpikir secara kronologis dalam mempelajari ilmu fisika sehingga hasil belajar siswa lebih meningkat. Metode eksperimen ini sejalan dengan amanat kurikulum 2013 yang lebih menekankan pada proses pembelajaran. Sebagaimana disebutkan Sudrajat (2013) bahwa kehadiran kurikulum 2013 menjadikan siswa lebih aktif dalam mengkonstruksi pengetahuan dan keterampilannya, juga dapat mendorong siswa untuk melakukan penyelidikan guna menemukan fakta-fakta dari suatu fenomena atau kejadian. Artinya, dalam proses pembelajaran, siswa dibelajarkan dan dibiasakan untuk menemukan kebenaran ilmiah, bukan diajak untuk beropini dalam melihat suatu fenomena.

Melalui metode eksperimen diharapkan tercipta proses pembelajaran yang kondusif, dimana para siswa dapat mengembangkan aktivitas dan kreativitas belajarnya secara optimal sesuai dengan kemampuannya masing-masing. Menurut Gibbs dalam Mulyasa (2002:106) mengatakan bahwa kretivitas dapat dikembangkan dengan memberi kepercayaan, komunikasi yang bebas, pengarahan diri dan pengawasan yang tidak terlalu ketat. Tulisan ini akan membahas tentang bagaimana implementasi metode eksperimen pada materi Gelombang Mekanik dalam meningkatkan hasil belajar fisika siswa kelas XI MIPA SMA.

\section{METODE PENELITIAN}

Penelitian ini merupakan Penelitian Tindakan Kelas (PTK) atau Classroom Action Research (CAR). Model penelitian tindakan kelas yang dipakai adalah model Spiral dari Kemmis dan Taggart dalam Rochiati Wiraatmadja (2009) yang dilakukan dalam 4 tahapan tindakan penelitian yaitu perencanaan (plan), tindakan (act), pengamatan (observe), refleksi (reflect). Tahap Perencanaan memuat pembuatan Rencana Pelaksanaan Pembelajaran (RPP) dengan metode eksperimen, pembuatan Lembar Kerja Siswa (LKS) dengan topik gelombang mekanik dan diadakan sosialosasi tentang metode eksperimen kepada siswa. Tahap Pelaksanaan dan pengamatan dilakukan dengan pembelajaran langsung menggunakan metode eksperimen dalam waktu 2 x 45 menit tiap siklus. Tahap refleksi dilakukan dengan menganalisis data dan hasil observasi yang dilakukan. Hasil refleksi dari siklus 1 menjadi penentu langkah-langkah yang akan dilakukan pada siklus berikutnya. 


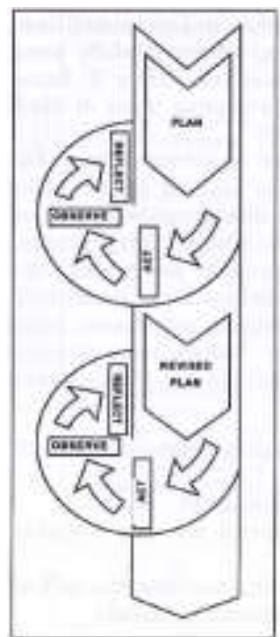

\section{Gambar 2.1 Langkah yang dilakukan pada tiap siklus}

Teknik pengumpulan data dalam penelitian ini adalah dengan observasi langsung untuk mengetahui kemampuan merencanakan eksperimen, membuat data, mengolah data, menganalisis data, menghitung, menganalisis grafik, mensintesa, membuat kesimpulan dan kelengkapan proses eksperimen.. Dokumentasi digunakan untuk memperoleh berbagai arsip atau data berupa kurikulum, Rencana Pelaksanaan Pembelajaran (RPP), hasil pekerjaan siswa, dan nama responden penelitian. Dokumentasi berupa foto dan video saat proses pembelajaran berlangsung yang terkait dengan masalah penelitian. Tes diberikan kepada siswa kelas XI MIPA dalam bentuk pilihan ganda dan essay. Waktu pelaksanan tes dilakukan pada awal pertemuan sebagai pre test, kemudian diadakan post test padi setiap akhir pelaksanaan siklus. Pemberian tes ini dimaksudkan untuk mengetahui seberapa jauh hasil yang diperoleh siswa kelas XI MIPA setelah kegiatan pemberian tindakan mulai awal sampai akhir.

Teknik analisis data dalam penelitian ini adalah reduksi data, penyajian data dan penarikan kesimpulan. Data yang direduksi adalah tes awal yang berkaitan dengan materi, observasi mengenai penggunaan metode eksperimen pada saat pemberian tindakan berlangsung terhadap materi yang telah ditentukan atau data yang mendukung penelitian. Data yang disajikan adalah data observasi dan hasil tes yang dilakukan di kelas XI MIPA tentang pemberian tindakan dalam peningkatan hasil belajar fisika. Penarikan kesimpulan dengan diverifikasi kebenaran, kekokohan, dan kecocokkan makna-makna yang muncul dari data. Pelaksanaan verifikasi merupakan suatu tujuan ulang pada pencatatan lapangan atau peninjauan kembali serta tukar pikiran dengan teman sejawat.

Untuk mengetahui tingkat keberhasilan siswa dari segi proses belajar dilakukan pengamatan terhadap keterampilan eksperimen siswa. Penilaian keterampilan eksperimen didasarkan pada tabel tingkat penguasaan, sebagaimana dalam Muhibin Syah (1995). 
Tabel 2.1 Tingkat Penguasaan

\begin{tabular}{cc}
\hline Nilai $(\%)$ & Kategori Keterampilan \\
\hline Nilai $>\mathbf{8 0}$ & Sangat Baik \\
$\mathbf{6 0}<$ Nilai $\leq \mathbf{8 0}$ & Baik \\
$\mathbf{4 0}<$ Nilai $\leq \mathbf{6 0}$ & Cukup \\
$\mathbf{2 0}<$ Nilai $\leq \mathbf{4 0}$ & Kurang \\
Nilai $<\mathbf{2 0}$ & Sangat Kurang \\
\hline
\end{tabular}

Menurut Mulyasa (2006) mengatakan bahwa kualitas pembelajaran dapat dilihat dari sesi proses dan dari segi hasil. Dari segi proses, pembelajaran dikatakan berhasil dan berkualitas, apabila seluruh atau setidak-tidaknya sebagian besar $75 \%$ peserta didik terlibat secara aktif baik fisik maupun mental dalam proses pembelajaran. Disamping itu siswa juga harus menunjukkan kegairahan belajar yang tinggi, semangat belajar yang besar dan rasa percaya diri yang tinggi. Sedangkan dari segi hasil, proses pembelajaran dikatakan berhasil apabila terjadi perubahan tingkah laku yang positif pada diri peserta didik. Indikator prestasi belajar dari penelitian ini adalah jika beberapa dari siswa telah mencapai nilai minimal 71 dengan indikator yang meningkat. Penetapan nilai 71 didasarkan nilai KKM mata pelajaran fisika.

\section{HASIL PENELITIAN DAN PEMBAHASAN}

\subsection{Hasil Observasi Keterampilan Eksperimen Siswa}

Berdasarkan observasi, keterampilan siswa saat pembelajaran menggunakan metode eksperimen di siklus I dan siklus II pada awalnya memang siswa terlihat enggan untuk melaksanakan eksperimen. Namun dengan dorongan dan motivasi dari guru, eksperimen yang dilakukan pada pertemuan-pertemuan selanjutnya berjalan dengan lebih lancar karena siswa mulai terbiasa melakukan eksperimen. Pada saat siklus II sudah mulai muncul antusiasme dari siswa, dan bahkan beberapa dari mereka tak segan bertanya jika mengalami kesulitan dalam memahami materi eksperimen. 


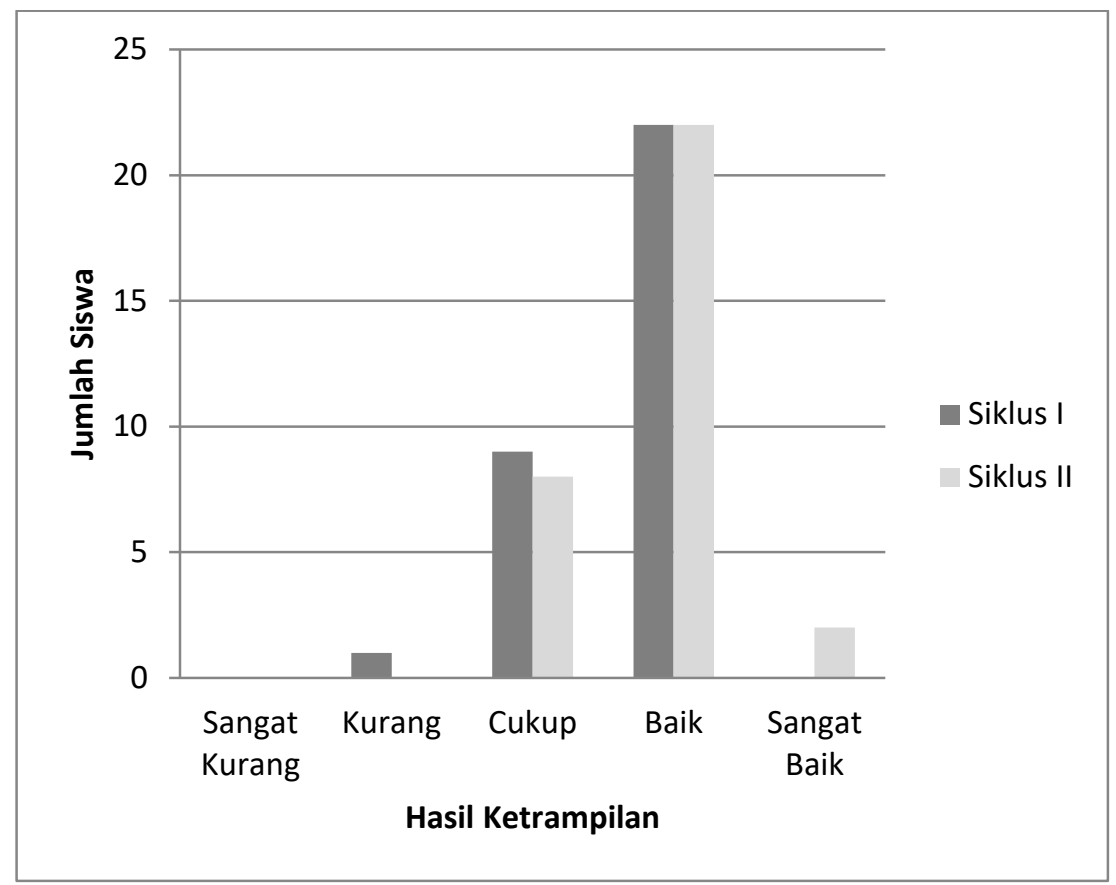

Gambar 3.1 Grafik Hasil Observasi

\section{Keterampilan Eksperimen Siklus I dan Siklus II}

Berdasarkan grafik tersebut terlihat bahwa rata-rata keterampilan eksperimen siswa kelas XI MIPA ada pada kategori baik. Terjadi peningkatan dari siklus I ke siklus II. Pada siklus I terdapat siswa yang mempunyai nilai keterampilan pada kategori kurang. Sedangkan pada siklus II tidak terdapat siswa yang mempunyai nilai keterampilan pada kategori rendah. Selain itu pada siklus II terdapat siswa dengan kategori keterampilan eksperimen sangat baik, sedangkan pada siklus I tidak. Rata - rata nilai keterampilan eksperimen siswa pada siklus I adalah sebesar 62.11 (baik). Pada siklus II terjadi kenaikan rata-rata nilai keterampilan eksperimen siswa menjadi 66.21 (baik).

\subsection{Hasil Belajar Siswa}

Keberhasilan siswa dalam melakukan eksperimen diukur dengan diadakannya postest pada pertemuan ketiga setiap siklus. Postest ini juga merupakan alat untuk mengukur pemahaman siswa pada materi gelombang mekanik. Berikut ini disajikan hasil pretest, postest siklus I dan postest siklus II.

Rata-rata nilai pretest siswa adalah 47,34, kemudian mengalami peningkatan pada siklus I menjadi 55,15, dan pada siklus II kembali mengalami peningkatan menjadi 60,47. Begitu pula dengan jumlah siswa dengan nilai tuntas. Pada saat pretest terdapat 5 siswa tuntas, meningkat menjadi 9 siswa pada siklus I, kemudian pada siklus II meningkat kembali menjadi 14 siswa dengan nilai tuntas. 


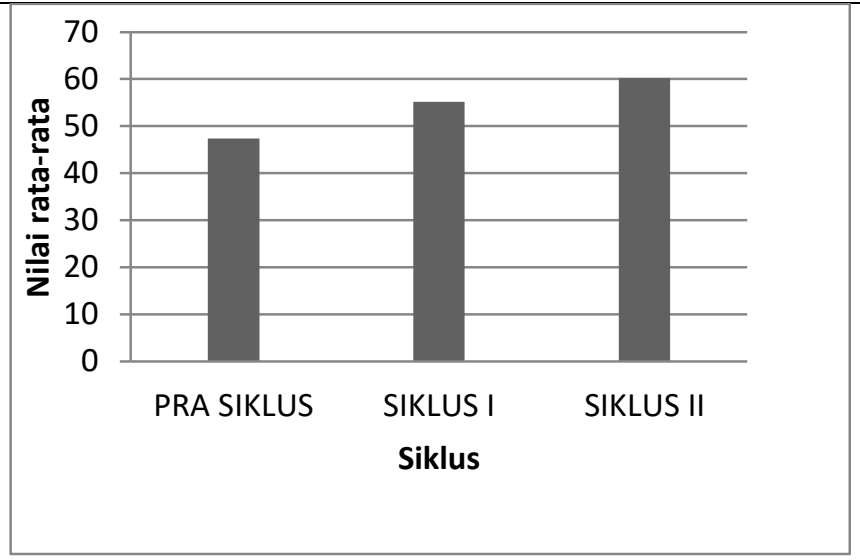

Gambar 3.2 Grafik Rata-Rata Hasil Belajar Siswa Setiap Siklus

Kelas XI MIPA merupakan siswa dengan minat belajar yang sangat rendah, akibatnya hasil belajar yang di peroleh selalu rendah bahkan untuk mencapai nilai KKM saja, hanya segelintir orang yang dapat mencapainya. Hal ini sangat meresahkan pihak akademis terlebih guru yang mengajar di kelas tersebut. Berangkat dari hal tersebut peneliti melakukan penelitian tindakan kelas untuk mengubah pola belajar dalam hal ini mengasah keterampilan eksperimen siswa dengan harapan dapat meningkatkan hasil belajar siswa kelas XI MIPA. Pembelajaran menggunakan metode eksperimen merupakan pembelajaran yang dinilai efektif karena siswa dididik sampai tahap pembuktian teori. Peningkatan keterampilan eksperimen siswa pada penelitian ini berpengaruh pada tingkat pemahaman siswa terhadap materi gelombang mekanik. Hal ini diikuti dengan meningkatnya hasil belajar siswa.

\section{SIMPULAN}

Berdasarkan Penelitian Tindakan Kelas (PTK) melalui dua siklus yang telah dilakukan pada siswa kelas XI MIPA SMA mata pelajaran fisika materi gelombang mekanik, dapat disimpulkan bahwa:

1. Penggunaan metode eksperimen dalam pembelajaran fisika dapat meningkatkan ratarata keterampilan eksperimen siswa dari 62,1 menjadi 66,2.

2. Pembelajaran fisika dengan metode eksperimen dapat meningkatkan hasil belajar siswa yang ditandai dengan peningkatan nilai rata-rata hasil pretest sebesar 47,3 postest siklus I sebesar 55,2 meningkat menjadi 60,5 pada siklus II. 


\section{DAFTAR RUJUKAN}

Anderson, L. A. dan Krathwohl, D. R. (2010). Kerangka Landasan untuk Pembelajaran, Pengajaran, dan Asesmen: Revisi Taksonomi Pendidikan Bloom. ( Agung Prihantoro, Terjemahan). Yogyakarta: Pustaka Pelajar. Buku asli diterbitkan tahun 2001.

Arikunto, Suharsimi. (2006). Prosedur Penelitian Suatu Pendekatan Praktik, Edisi revisi VI, Jakarta: Rineka Cipta, Cet. XIII.

Ghony, M. Djunaidi. (2008). Penelitian Tindakan Kelas. Malang: UIN-Malang Press.

Mulyasa. (2006). Kurikulum Tingkat Satuan Pendidikan. Bandung: PT Remaja Rosdakarya.

Rismawati, Ratman, dan Andi Imrah Dewi. 2016. Penerapan Metode Eksperimen dalam Meningkatkan Pemahaman Konsep Energi Panas pada Siswa Kelas IV SDN No.1 Balukang 2. Palu: Jurnal Kreatif Tadulako

Roestiyah, N.K. (2012). Strategi Belajar Mengajar. Jakarta: Rineka Cipta.

Sudjana, Nana. (2002). Penilaian Hasil Belajar Mengajar. Bandung : Remaja.

Sudrajat, Ahmad. (2013). Teori Pendidikan dan Kurikulum. Diakses tanggal 5 Desember 2018 dari http://www.akhmadsudrajat.wordpress.com/

Suparwoto. (2007). Dasar-Dasar dan Proses Pembelajaran Fisika. Yogyakarta: DIPA UNY.

Suryabrata, S. (1993). Metodologi Penelitian. Jakarta: CV Rajawali.

Susilo. (2013). Metode Penelitian Bidang Pendidikan Kualitatif, Kuantitatif, dan Campuran. Yogyakarta: Kanwa Publisher.

Syah, Muhibbin. (1995). Psikologi Pendidikan Suatu Pendekatan Baru. Bandung: Remaja Rosdakarya.

Toharudin, Uus, Sri Hendrawati, Andrian Rustaman. (2011). Membangun Literasi Sains Peserta didik. Bandung : Humaniora.

Wiraatmadja, Rochiati. (2009). Metode Penelitian Tindakan Kelas. Bandung: PT Remaja Rosdakarya. 
